\title{
Synthesis of antibacterial additive for metal working fluids application
}

\author{
Ezzat Hamed ${ }^{1}$, Nagy Saker $^{2}$, Shawky ElShazly ${ }^{1}$, Tarek Fahmy ${ }^{3}$, and Yasser Aboulazm ${ }^{2}$ \\ ${ }^{1}$ Faculty of science, Alexandria University, Alexandria, Egypt \\ ${ }^{2}$ Research Center, Misr Petroleum Company, Egypt \\ ${ }^{3}$ Alexandria Specific Petroleum Products Company, Alexandria, Egypt
}

\begin{abstract}
Metalworking fluids, the class of lubricants most susceptible to microbial attack, metalworking fluid must also be safe for human use and exposure, The failure of the fluid to perform any of its functions has the potential to result in operational problems, process shutdowns, decreased tool life, and productquality issues, all of which will result in increased costs. Perhaps one of the most common and controllable complications is microbial degradation specially standing from the fact that metalworking fluids contain the nutrients that can permit unchecked microbial growth. In this work we prepared Antimicrobial metal working fluid additive which fulfills the criteria of successful local production in Egypt, as the commercial availability of starting components, effectiveness of the prepared additive, easiness of addition and homogenization with other MWF additives, good environmental profile and biodegradability. The effectiveness of the prepared additive was evaluated by standard method ASTM E645-97 test. It was revealed that; the formic acid which condensate with the polyethylene glycol 400 and ethylene glycol had excellent antibacterial action, it could also greatly reduce growth of bacteria.
\end{abstract}

\section{Introduction}

Microbial contamination may cause some health problems for workers such as skin irritation and dermatitis, and respiratory problems. Hypersensitivity pneumonitis (HP), the most severe condition, has been attributed to the presence of Mycobacterium immunogenum in contaminated fluid mists [1]. Endotoxins, which are cell wall fragments of gramnegative bacteria that may be found in metalworking fluids, may cause respiratory impairment, and mycotoxins, produced by fungi in contaminated fluids. These situations continue to be explored; Passman [2] has very recently provided a detailed discussion of worker health issues. The American Society for Testing and Materials (ASTM) Subcommittee E34.50 on Health and Safety Standards for Metal Working Fluids have produced standard test methods for enumeration of mycobacteria (E2564-07) [3] and determination of endotoxin concentration (E2250-02) [4] in metalworking fluids.

Formaldehyde-condensate biocides exhibit a broad spectrum of antimicrobial activity; they are by far the most popular and proven biocide chemistries for metalworking fluid applications. They control microbiological growth through their ability to generate formaldehyde in situ. Its antimicrobial activity is derived from an electrophilic active group that reacts with nucleophilic cell sites. These targets include amino acids or proteins, which are often important components of enzymes or other functional proteins critical to cell function $[5,6]$.

Our aim of the work was to prepare effective, local market available and affordable components, with good environmental profile.

In order to achieve that esterification reaction between the glycols(s) and formic acid using para-toluene sulfonic acid as catalyst, Xylene as an azeotropic solvent (as shown in equation 1). The using of Azeotropes to remove water and removing it, drives the equilibrium in favor of the ester product. [7]

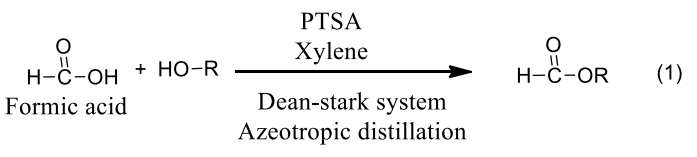

Then the obtained esters were tested using standard method ASTM E645-97 test, showed excellent antibacterial results for both condensates.

\section{Materials and methods}

\subsection{Materials}


The IR spectra were recorded using Perkin-Elemer FT-IR spectrophotometer. Reactions were routinely followed by thin layer chromatography (TLC) using Merck Kiesel gel using eluent n-Hexane (8): Ethyl acetate (2); 60F254 precoated plastic plates and the spots were detected by UV light absorption, the antimicrobial studies were performed at the microbiological laboratory, Misr Petroleum Company, Egypt. Chemicals were obtained from the local market.

\subsection{Reaction method}

In a two necked round bottom flask equipped with StarkDean separation adaptor equivalent amount of Ethylene glycol, or Poly ethylene glycol were placed, a thermometer was placed in a neck while the Stark-Dean adaptor was placed into the other neck using Xylene as azeotropic solvent, the system was placed on a hot plate equipped with magnetic stirrer. Catalytic amount of Para Toluene Sulfonic Acid (PTSA) was added (one gram for each hundred mille of reactants). The reaction mixture left to reflux with stirring at temperatures of $90^{\circ} \mathrm{C}$, reaction progress was traced by TLC. After completion of reaction noticed from the acidity test and the separated water, the reaction mixture was washed with $20 \mathrm{ml}$ of $10 \%$ aqueous sodium carbonate and $100 \mathrm{ml}$ water, extracted using Benzene, dehydrated using anhydrous sodium sulphate and left for solvent evaporation. Spectral analysis was used to identify and proof the structure.

2.2.1. Reaction of Ethylene glycol with Formic acid (compound 1): $56.4 \mathrm{ml}$ of Ethylene glycol (1 mol.) with $115.075 \mathrm{ml}$ of Formic acid (2.2 mol.) were refluxed for 7 hours at $90^{\circ} \mathrm{C}$ to produce ethane-1,2-diyl diformate (1). IR $v \mathrm{~cm}^{-1}: 2954.72$ (CH Aliphatic), $1721.96(\mathrm{C}=\mathrm{O})$.

2.2.2. Reaction of poly ethylene glycol with Formic acid (compound 2):: $44.32 \mathrm{ml}$ of poly ethylene glycol $(0.125$ mol.) with $10.153 \mathrm{ml}$ of Formic acid $(0.1875$ mol.) were refluxed for 5 hours at $90^{\circ} \mathrm{C}$ to produce polyethylene glycol formate (2). IR $\mathrm{c} \mathrm{cm}^{-1}: 2875.21$ (CH Aliphatic), $1719.55(\mathrm{C}=\mathrm{O})$.

2.2.3. Reaction of Ethylene glycol with acetic anhydride (compound 3): $14.05 \mathrm{ml}$ of Ethylene glycol (0.25 mol.) with $35 \mathrm{ml}$. (excess amount) of acetic anhydride were refluxed for 5 hours at $110-120^{\circ} \mathrm{C}$ to produce ethane-1,2diyl diacetate (3). IR $0 \mathrm{~cm}^{-1}: 2961.81$ (CH Aliphatic), $1746.42(\mathrm{C}=\mathrm{O})$.

2.2.4. Reaction of poly ethylene glycol with acetic anhydride (compound 4): $44.326 \mathrm{ml}$ of poly ethylene glycol (0.125 mol.) with $14.318 \mathrm{ml}$. (1.1 equivalents) of acetic anhydride were refluxed for 8 hours at $160{ }^{\circ} \mathrm{C}$ to produce polyethylene glycol acetate (4). IR $0 \mathrm{~cm}^{-1}$ : 2873.85 (CH Aliphatic), $1740.21(\mathrm{C}=\mathrm{O})$.

\section{Evaluation tests}

We used the following tests to evaluate the action of the prepared additives and also the performance and effect on other final product properties.

2.3.1. IP 311: This method covers the determination of the thermal stability of water mix metal working fluids over the range of temperatures at which the fluids would normally be stored. We perform this test to insure that the prepared additive don't affect the thermal stability of the final product after mixing with other components.

2.3.2. IP 312: This method assesses the frothing characteristics of water mix metal working fluids used in the form of aqueous dilutions.

2.3.3. IP 263: Water mix metal working fluids used in the form of aqueous dilutions should remain stable in use. This method is accordingly designed to assess the stability of water mix metal working fluids used in the form of aqueous dilutions.

2.3.4. IP 125: This standard specifies a procedure for the assessment of the corrosion characteristics of water-mix metal working fluids, in the form of aqueous dilutions, when in contact with cast iron. It is applicable to premixed aqueous dilutions or to supply concentrates which are diluted in the manner described in IP 263. Metal working fluids should not permit the corrosion of metals with which they come into contact, and cast iron is chosen as a typical sensitive example of such metals.

2.3.5. ASTM E645-97: this test method outlines a procedure for evaluating the efficacy of microbicides (algaecides, bactericides, and fungicides) that will be used for controlling microbial growth in cooling water systems. The microbicides will be evaluated using simulated or real cooling tower water against microbes from cooling water, microbiological deposits (biofilms) from operating cooling systems, or microorganisms known to contaminate cooling water systems, or combination thereof.

\section{Results}

The antibacterial investigation using the ASTM E645-97 method results shown in the following table:

Table 1. The antibacterial analysis ASTM E645-97 results.

\begin{tabular}{|c|c|c|c|c|}
\hline $\begin{array}{c}\text { Percentage } \\
\text { added }\end{array}$ & $\begin{array}{c}\text { compound } \\
1\end{array}$ & $\begin{array}{c}\text { compound } \\
2\end{array}$ & $\begin{array}{c}\text { compound } \\
3\end{array}$ & $\begin{array}{c}\text { compound } \\
4\end{array}$ \\
\hline 0.1 & Not visible & Growth & $\begin{array}{c}\text { Over } \\
\text { growth }\end{array}$ & $\begin{array}{c}\text { Over } \\
\text { growth }\end{array}$ \\
\hline 0.2 & Not visible & Growth & $\begin{array}{c}\text { Over } \\
\text { growth }\end{array}$ & $\begin{array}{c}\text { Over } \\
\text { growth }\end{array}$ \\
\hline 0.3 & Not visible & Growth & $\begin{array}{c}\text { Over } \\
\text { growth }\end{array}$ & $\begin{array}{c}\text { Over } \\
\text { growth }\end{array}$ \\
\hline 0.4 & Not visible & Growth & $\begin{array}{c}\text { Over } \\
\text { growth }\end{array}$ & $\begin{array}{c}\text { Over } \\
\text { growth }\end{array}$ \\
\hline 0.5 & Not visible & $\begin{array}{c}\text { Slight } \\
\text { growth }\end{array}$ & $\begin{array}{c}\text { Over } \\
\text { growth }\end{array}$ & $\begin{array}{c}\text { Over } \\
\text { growth }\end{array}$ \\
\hline 1 & - & - & $\begin{array}{c}\text { Over } \\
\text { growth }\end{array}$ & $\begin{array}{c}\text { Over } \\
\text { growth }\end{array}$ \\
\hline
\end{tabular}


Table 2 . The evaluation tests result for effective biocides

\begin{tabular}{|c|c|c|}
\hline Test & compound 1 & compound 2 \\
\hline IP 311 & No separation & No separation \\
\hline IP 312 & Cream, 0.1 & Cream, 0.1 \\
\hline IP 263 & Oil, Nil & Oil, Nil \\
\hline IP 125 & $0 / 1-1$ & $0 / 1-1$ \\
\hline
\end{tabular}

\section{Discussion and conclusions}

The esterification reaction has taken place between organic acids (formic) or acid anhydride (acetic anhydride) and glycols (ethylene glycol and/or poly ethylene glycol) using the azeotropic conditions with the Lewis acid (PTSA) gave successfully the corresponding esters as shown in Equation1. The reactions of formic acid shown in equations 2,3 giving the effective biocide compounds 1 and 2 . The 2 equivalent molecules of formic acid were used for the condensation with the two hydroxyl groups of the glycol molecule, Para-toluene sulfonic acid was used as Lewis acid for the successful catalysis of the esterification reaction. While the resulted condensate water was separated using xylene as azeotrope in the system equipped with Dean-Stark adaptor.

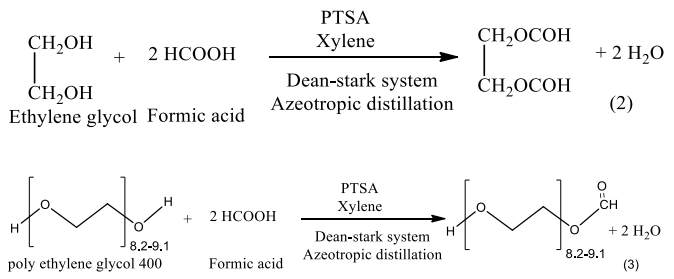

The results stated in Table 1 shows that the reaction between ethylene glycol and formic acid gave the best product (ethane-1,2-diyl diformate) with antibacterial effect, while the same reaction with polyethylene glycol 400 gave less potent antibacterial compound (polyethylene glycol formate).

While preparation of antibacterial compounds using acetic anhydride gave almost negative results with both ethylene glycol (ethane-1,2-diyl diacetate); and polyethylene glycol (polyethylene glycol acetate).

That advance of the formyl condensates may be attributed to the high electrophilic active group that reacts with nucleophilic cell sites of the bacteria affecting the cell activity and wall.

The relative higher antibacterial effect of the mono ethylene glycol condensate over that of the poly ethylene glycol condensate may be attributed to the easy dissociation of the formyl group from the mono ethylene glycol over that of the bulky polyethylene glycol where steric hindrance and molecular size may affect the dissociation ability of the formyl group.

The evaluation tests were performed to the already successful compounds 1 and 2. They showed no effect on the thermal stability (IP 311) or the emulsion stability as shown with the IP 312 and IP 263, respectively. Also IP 125 showed that the prepared compounds don't permit the corrosion of metals.

\section{References}

1. Rossmoore, H.W., L. Rossmoore, D. Bassett. Life and death of mycobacteria in the metalworking environment. Lubes'N'Greases 21-27, April (2004).

2. Passman, F.J. Metalworking fluid microbes: What we need to know to successfully understand causeand- effect relationships. Tribol Trans 51(1): 107-117, (2008).

3. ASTM E2564-07, Standard test method for enumeration of mycobacteria in metalworking fluids by direct microscopic counting (DMC) method, Annual Book of Standards, vol. 11.03, Philadelphia, (2007).

4. ASTM E2250-02, Standard method for determination of endotoxin concentration in water miscible metal working fluids, Annual Book of Standards, vol. 11.03, Philadelphia, (2002).

5. Sondossi, M., H.W. Rossmoore, J.W. Wireman. Observations of resistance and cross-resistance to formaldehyde and a formaldehyde condensate biocide in Pseudomonas aeruginosa. Int Biodetn 21: 105-106, (1985).

6. Sondossi, M., H.W. Rossmoore, R. Williams Relative formaldehyde resistance among bacterial survivors of biocide-treated metalworking fluids. Int Biodetn 25: 423-437, (1989).

7. L. H. Horsley in R. F. Gould, ed., Azeotropic DataIII, American Chemical Society, Washington, D.C., (1973). 